\title{
Cultural Communications of the Diplomatic Corps as a Public Institution
}

\section{Oksana Zakharova}

National Academy of Culture and Arts Management, Kyiv, Ukraine

\begin{abstract}
In the 18th - early 20th centuries, state ceremonial was an integral part of the system of government of European monarchies. They played a significant role in the legitimisation of power institutions (the coronation ceremony), in the administration of foreign and domestic political, ideological and cultural functions by the state. One of the first places in the hierarchy of state ceremonials is occupied by the diplomatic ceremony, in the process of preparation and in the conduct of which the leading role belongs to the representatives of the diplomatic corps. Their activities make it possible to solve these protocol and ceremonial issues more quickly. The diplomatic corps is the collective body of heads of diplomatic missions accredited to a particular government. The relevance of the study lies in exploring the role of art in diplomatic communications, which are one of the methods of building partnerships between states. The purpose of the study is to prove that culture is an important communicative factor in the system of diplomatic relations. There are no published studies on this problem in historiography. The source database includes two groups of materials: documentary publications and archival materials. The diplomatic corps is a public institution in the life of which art is one of the most important communicative factors. As a result of the study, the following main lines of communication were identified: diplomatic corps - government, government - diplomatic corps, diplomatic corps - public organisations, diplomatic corps - People's Commissariat of Foreign Affairs, People's Commissariat of Foreign Affairs (Ministry of Foreign Affairs) - diplomatic corps.
\end{abstract}

Keywords---attaché, embassy, envoy, policy, protocol.

\section{Introduction}

The diplomatic corps is a body of heads of diplomatic missions accredited to any government. They are: ambassadors, envoys, permanent chargé d'affaires, chargé d'affaires ad interim, as well as nuncios and internuncios who are heads of

Linguistics and Culture Review (c) 2021.

Corresponding author: Zakharova, O.; Email: zakharova7922@toronto-uni.com

Manuscript submitted: 19 June 202 1, Manuscript revised: 18 Sept 2021, Accepted for publication: 27 Oct 2021 
Vatican diplomatic missions (Molochkov, 1977; Scoville, 2019). In addition to them, members of the diplomatic corps are staff and other persons enjoying diplomatic status. In the broadest sense of the word, the diplomatic corps means, along with the heads of embassy missions, all members of the diplomatic staff, as well as other persons enjoying diplomatic status: military, air force and naval attachés and their assistants, as well as various specialists appointed to diplomatic positions (usually advisers or attachés): in scientific and technical cooperation, culture, agriculture (Kvasov, 2011; Lima \& de Oliveira, 2018; Watkins, 2019). The diplomatic corps also includes family members of the diplomatic staff and all the persons listed above: wives, unmarried daughters regardless of age and minor sons. The diplomatic corps is a single entity, it cannot be divided by the government into separate groups according to the class of diplomatic representatives (Wood \& Serre, 2016; Keys \& Yorke, 2019; Hogan et al., 2021).

The diplomatic corps is not an institution based on any norm of international law, nor is it a political association with the rights of a legal entity. This statement is confirmed in the statements of leading experts in the field of international law. Pradee-Fodere (1881), gives the following definition to the concept of "diplomatic corps": "The diplomatic corps is neither a legal nor a political entity. This is just an association of persons completely independent from one another". Gene (1931), notes: "The diplomatic corps cannot be called an association with legal rights". de Melu (1953), recognises that "the diplomatic corps is a collective organisation", but at the same time notes that the diplomatic corps "is neither a legal entity nor a political institution". Thus, the diplomatic corps, being a set of separate independent representative offices located in one place and engaged in one kind of activity, is not an institution based on any norm of international law, acting as a political organisation (Dodd \& Collins, 2017; Yun, 2007). However, taking into account international traditions, it is recognised as a public institution with limited functions. Local legislation does not regulate business and personal contacts of diplomats who follow the instructions of their governments in these matters, as well as the traditions established in the diplomatic corps (Lyadov, 2018).

The source database includes two groups of materials: documentary publications and archival materials (Robinson \& Martin, 2017). The published sources are represented by documents of personal origin, among which special attention should be paid to the memoirs of the Latvian diplomat, Ambassador to Washington, Envoy Extraordinary and Minister Plenipotentiary of Latvia to the USSR (Union of Soviet Socialist Republics) Ozols (2015), who was arrested on August 25, 1940, and sentenced to death by the Military Collegium of the Supreme Court of the USSR on June 23, 1941. While in the diplomatic service in Moscow, Ozols (2015), concluded a non-aggression and trade agreement. In order to cover the issue comprehensively, it was necessary to use the archive materials of the Protocol Department (057 and 57) of the Foreign Policy Archive of the Russian Federation (2021). Of particular interest from the point of view of studying the cultural communications of the diplomatic corps in Moscow are the unpublished diaries of the head of the Protocol Department, the founder of the diplomatic Protocol of the USSR, D.T. Florinsky (AVP RF. F. 057. Op. 3. P. 101. D. 1.). In 1934, the "Florinsky Case" was the beginning of Stalin's repressions 
against diplomats of the People's Commissariat for Foreign Affairs (NKID) (since 1946 - the Ministry of Foreign Affairs (MFA)). Employees of the Protocol Department attempted to "try on" the norms of Jewish diplomatic protocol with the norms of Soviet ideology. The study of the place and role of art in the process of this activity is one of the objectives of the study. The novelty of the study consists in considering the characteristics of the diplomatic corps' stay in Moscow during the Soviet period. The purpose of the study is to prove that culture is an important communicative factor in the system of diplomatic relations (Tödtling \& Trippl, 2005; Lockett et al., 2005).

\section{The diplomatic corps as a public institution}

The diplomatic corps cannot make political demands to the Government, collective protests are rejected as illegal, and collective speeches are allowed only in the field of ceremonial issues, if they are not of a political nature (Sreejith, 2019). In the early years of Soviet power, three performances of the diplomatic corps are known. In connection with the disarmament of troops in Bessarabia by the Romanian government, the deprivation of their food, the executions in Petrograd in January 1918, the Romanian envoy Diamandi was arrested. On January 14, the heads of diplomatic missions arrived in Smolny to hand V.I. Lenin a memorandum demanding the immediate release of the diplomat. At the meeting, to the statement of French Ambassador Noulance, Belgian Envoy Destree and Serbian Envoy Spolajkovic that the identity of the diplomatic representative was inviolable under any circumstances, V. I. Lenin replied that 'for a socialist, the life of a thousand soldiers is dearer than the peace of mind of one diplomat' (Molochkov, 1977). On January 26, 1918, the Council of People's Commissars decided to break off diplomatic relations with Romania. On February 15, 1918, the diplomatic corps sent a note to the People's Commissariat of Foreign Affairs, thereby protesting the decree of the All-Russian Central Executive Committee (VTsIK) of January 28, 1918, in which loans from other countries and state debts of the Russian Empire were cancelled. On September 6, 1918, the Doyen of the diplomatic corps in Petrograd, the Swiss envoy Odier, on behalf of the diplomatic corps, sent a note of protest to the People's Commissariat for Foreign Affairs "against the regime of terror established in Petrograd, Moscow and other cities" (Molochkov, 1977). The protest was dismissed as an attempt to support the counter-revolution.

Collective performances of the diplomatic corps are possible only on ceremonial (protocol) issues. In most cases, the diplomatic corps is represented by its doyenne, who, as a rule, is "the head of the diplomatic mission of the highest rank, who presented the credentials before others" (Wood \& Serre, 2016). Messages for all members of the diplomatic corps, which the Ministry of Foreign Affairs wishes to send to the heads of embassies, are transmitted through the doyen of the diplomatic corps. They take measures to inform colleagues. "Doyen must $\langle\ldots\rangle$ try to rally the diplomatic corps and maintain business and friendly relations between its members <..." (Wood \& Serre, 2016). The provisions of Articles 5 and 6 of the resolutions of the Congress of Vienna of 1815 state that "a uniform procedure for the reception of diplomatic agents of each class should be established in each state" and that "ties of kinship or family ties between courts do not create any advantages in rank for their diplomatic agents" (Molochkov, 
1977). These provisions, which also apply to political unions, were generally recognised before the Vienna Convention on Diplomatic Relations (1961) and formed the basis of the rules of diplomatic ceremonial of all countries. In some countries, the Vatican Ambassador (nuncio) has diplomatic seniority over other ambassadors, regardless of the time of arrival in the host country or the date of presentation of credentials (Moro et al., 2020; Baack \& Singh, 2007). By virtue of this tradition, the nuncio is the doyen of the diplomatic corps. Doyen advises colleagues on issues of local protocol and etiquette and relations with authorities. They perform at ceremonies, brings congratulations, condolences, organises the presentation of gifts (Sundqvist et al., 2005; Keller et al., 2008). The peculiarity of the position of doyen is that they must express the opinion of colleagues while remaining a representative of the country. The role of doyen allows the diplomat to act in two main directions.

The first is to maintain official relations between the government of the country they represent and the government to which they are accredited. The Ambassador conducts negotiations, makes oral statements, hands over and receives memoranda, notes, letters and other documents (Korolova et al., 2021; Diachenko et al., 2021). Another area of activity in which each of the members of the diplomatic corps can be involved, regardless of their rank, involves establishing contacts with representatives of political and public circles, cultural figures. As the USSR Ambassador to London Maisky (1971), notes in his memoirs: "<...> without such connections, he (the ambassador - auth.) will not be able to orient himself properly in the surrounding environment, nor to influence the views and moods of both the ruling strata and the broad masses of this country in the spirit he desires. The second function of an ambassador in modern conditions is very important and sometimes surpasses the first function in its significance, especially in countries with a well-developed social life like England or the United States of America (USA)". The second function is carried out during meetings of a diplomat with personalities of interest to him at receptions at embassies or with local residents. Usually in such cases, invitations are sent to husbands along with their wives. If the ambassador himself invites members of the diplomatic corps to lunch, breakfast, tea, then his wife acts as the hostess of the reception (Ginaya et al., 2018; Suwija et al., 2019).

In general, three "main concentric circles of relations" of a diplomatic employee should be distinguished: "external" - people who have a friendly or neutral attitude to the state that the diplomatic employee represents. The embassy does not maintain constant contacts with them and invites them on special occasions, for example, up to 700-800 people gathered at the USSR Embassy in London for a reception on November 7. For the English, it is important that there is a "crowd" - evidence that the reception has been a success (Wesnawa \& Sudirta, 2017). From the point of view of "benefit", this circle of connections is of the least importance. The second circle of connections are people with whom more regular relationships are maintained (about 200 people, they are often invited to small receptions, lunches, breakfasts, teas, musical evenings, film screenings. Among these persons are prominent representatives of politics, economics, science, literature, and art. From the point of view of diplomatic "usefulness", they represent "serious value". The third is the narrowest circle of the embassy's contacts, only 50 people with whom permanent and friendly ties were maintained: 
high-ranking officials, well-known politicians and business people, editors of major publications, famous writers and scientists. It is this circle, from the point of view of "diplomatic usefulness", that is of the greatest importance. Maisky (1971), emphasises that for him, as a diplomat, it was the "small receptions" that were of the greatest value - informal meetings at a table with a small (five, seven or ten people) number of participants who had integration and communication functions to the greatest extent.

\section{Cultural communications of the diplomatic corps in Moscow (1920s-1930s)}

Diplomats from other countries were in Moscow in an unusual socio-cultural environment for them, in which all means of communication were under strict control of the authorities. But the goals and objectives of the diplomatic service presuppose the right of a diplomat to choose a certain circle of communication that cannot be limited by the diplomatic corps. According to the data published in the reference book "Diplomatic Corps and Foreign Missions under the Government of the RSFSR (Russian Soviet Federative Socialist Republic)" published after the revolution (as of November 15, 1921), there were 15 official diplomatic missions in Moscow: the Embassy of Afghanistan, the Extraordinary Embassy of Persia, the Embassy of the Government of the Grand National Assembly of Turkey, the missions of Poland, Latvia, Lithuania, Estonia, Finland, plenipotentiary missions of a number of Socialist Soviet Republics that later became part of the USSR (Azerbaijan, Belarus, Ukraine, Armenia, Georgia), as well as the plenipotentiary missions of the Bukhara People's Soviet The Republic and the Far Eastern Republic (Lyadov, 2018). In addition, the Austrian Missions for Prisoners of War, the British Trade Mission, the Czech-Slovak Commercial and Industrial Mission and the Temporary Representation of the German Government operated as diplomatic missions.

Official representative offices of Russia abroad in the early 1920 s were also very few. At the end of 1921, the actual diplomatic missions headed by the plenipotentiaries were only in Germany, Latvia, Lithuania, Estonia, Finland, Persia, Turkey, as well as in Georgia, Bukhara and Khiva. In England, Italy and the Czech Republic, the RSFSR was represented by permanent chairmen of trade delegations, in Austria - by plenipotentiary representatives for prisoners of war. Representatives of the Russian Government were accredited in Mongolia, China (Kulja), the Far Eastern Republic and Tashkent, and the official representation of the Russian Red Cross Society was located in Switzerland. The above data require a certain critical approach, since almost half of the countries that established diplomatic relations with the RSFSR by the end of 1921 were state entities that arose on the territory of the former Russian Empire and then became part of the USSR. With regard to the procedure for establishing diplomatic relations, protocol practice has always proceeded from generally accepted international norms: the exchange of messages, telegrams, notes of identical content, the signing of a corresponding treaty or agreement. The agreement confirmed the establishment of diplomatic relations with Mongolia in 1921, China in 1924, Yemen in 1928, exchange of notes with France in 1924, Czechoslovakia in 1934 (Lyadov, 2018).

In the early 1920s, diplomats gathered every Sunday at the British mission, but People's Commissariat for Foreign Affairs employees were not invited to them. 
Representatives of the People's Commissariat had no opportunity to meet with citizens of other countries in restaurants. Lack of contacts - lack of information. This situation did not suit the Soviet side. One of the solutions to the problem is the opening of a diplomatic club in Moscow, a note on the organisation of which the head of the Protocol Department, D.T. Florinsky, wrote in January 1923. The official reasons for the opening are the request of the members of the diplomatic corps and the lack of contacts of Soviet diplomats with colleagues from other countries. "Rare official receptions with banal and formulaic conversations do not create the necessary intimacy and cannot serve the purposes of more or less serious information", D.T. Florinsky writes in a note (AVP RF. F. 057. Op. 3. P. 101. D. 1.). One of the important reasons, according to D.T. Florinsky, for the opening of the diplomatic club is the fact that the club will allow "observation of foreigners at a time when they are only in their environment - separate groups in the reading room, restaurant". Lunches, breakfasts and other receptions are conducive to frankness, the diplomats will be monitored by specially selected service personnel (AVP RF. F. 057. Op. 3. P. 101. D. 1.).

Chairman of the club D.T. Florinsky proposed appointing a Persian or German ambassador, each of whom can always be "put under friendly and private pressure in matters of interest to us" by the deputy chairman - a representative of the People's Commissariat for Foreign Affairs. The board also includes two representatives from the Soviet side and two foreigners. D.T.Florinsky offered to accept members of the diplomatic corps into the club without restrictions (the reason for refusal was an unworthy act of the candidate). For Soviet citizens, the strictest filtering (AVP RF. F. 057. Op. 3. P. 101. D. 1.). Despite the arguments of D.T. Florinsky, the authorities did not dare to open a club whose communicative and informational functions could bring not only benefit, but also harm to the Soviet side, which was afraid of information leakage. The problem of the diplomatic club was solved in March 1972, a cultural and sports complex for members of the diplomatic corps was opened in Moscow on Spiridonovka. Ozols (2015), recalled about the life of the diplomatic corps in Moscow: "Nowhere did the diplomatic corps live so amicably as in Moscow in the period 1923-1929. It is not just my opinion. I think all my colleagues would subscribe to these words, and at that time there were more than 170 of us in Moscow who enjoyed diplomatic immunity. This large family, especially in the person of its highest representatives, lived its own special life, fenced off from the rest of Russia. Isolation became our common cohesion, and seclusion, our detachment was caused by the Russian conditions of those years". The life of the diplomatic corps in Moscow in the early 1920s was very busy.

In his diary for 1923, D.T. Florinsky reports on almost daily receptions at embassies, as well as receptions organised by the Soviet side at the HermitageOlivier restaurant (AVP RF. F. 057. Op. 3. P. 101. D. 1.). Communication was based on a certain scenario: during lunch conversations about politics and art, then bridge and dancing. A kind of peak of diplomatic social life came in January. In 1927, on January 1, there was an afternoon reception at the wife of the Italian Ambassador Manzoni, at which the guests danced to the gramophone. In the period from January 1 to January 10, eight receptions were held in foreign missions - Latvian, Finnish, Danish, Polish, English, Italian, as well as an "intimate dinner" and bridge at the "Persians" - the guests danced not only on the 
parquet, but also on the ice rink (AVP RF. F. 057. Op. 7. P. 104. D. 1.). In 1926, receptions were organised on behalf of the People's Commissariat for Foreign Affairs board, at which the dance programme was preceded by a concert. So, on May 6, 1926, a board lunch for the heads of missions and a reception for the diplomatic corps took place, marking the end of the winter season. Obukhova, Yudin, Krieger performed. Sobinov, Nejdanova, Golovan performed the following evening. After the concert - a buffet, and then dancing to the piano (AVP RF. F. 057. Op. 6. P. 103. D. 1.). In the opinion of representatives of the diplomatic corps, the winter season of 1928 was rather boring "there are no general receptions for the diplomatic corps, but only prudish official dinners for the heads of missions and a small number of "chosen ones"'. Therefore, on January 14, the "tea reception" at the Greek Mission with dancing to the gramophone and bridge was very joyfully welcomed by the diplomatic corps and mainly by its female part. At this reception, the Turkish ambassador, who turned out to be a good dancer, "enthusiastically danced with Madame Herbette", the wife of the French Ambassador to the USSR (1924-1931) J. Herbette - one of the best French journalists, editor-in-chief of the newspaper "LeTemps" (AVP RF. F. 057. Op. 8. P. 105. D. 1.).

The ambassador carefully studied the life of the capital and six months after his arrival in Moscow, he was well versed in Soviet problems. The French Embassy did not give large receptions, but lunches and breakfasts were often arranged. The French ambassador did not play cards, he preferred to talk about politics, especially since there were enough topical subjects in Moscow. J. Herbette had exceptional working capacity, quickly learned the Russian language in which he could communicate. The Herbette couple were engaged in collecting. They managed to acquire rare copies of historical documents of the Russian reigning house, a collection of things from the Ural malachite and much more. The special trait of J. Herbette was his dislike of journalists who reciprocated him. The head of the German Embassy (until 1928), Count Brockdorff-Rantzau, a diplomat of the old "Bismarck school", an opponent of the Treaty of Versailles, was also fond of collecting. A consequence of the general Brockdorf-Rantzau policy was the lack of contacts with other diplomatic representatives. In his personal relationships, he adhered to the strict traditions of the past. "His dinner parties were held in the highest degree of discipline, as in no other embassy <...> Never more than 16 people sat at his table (this tradition was introduced by his mother, and he fulfilled her covenant - auth.)" (AVP RF. F. 057. Op. 8. P. 105. D. 1.). The count collected antique bronze, a large collection of which was kept in Germany. After one of the dinners, the People's Commissar of Education A.V. Lunacharsky, examining the bronze candelabra purchased in Russia at the embassy, noticed that if their owner had not been Brockdorf-Rantzau, he would never have allowed the candelabra with such high value to be taken out of Russia.

As Ozols (2015), notes in her memoirs: “<..> The German embassy knew Russia better than diplomatic representatives of other countries. They owe this familiarity $\langle\ldots\rangle$ to the German specialists, merchants, ranks of the General Staff, their acquaintances. However, even before the war, the Germans understood Russian affairs better than the British, Italians and even the French, Russia's allies". German discipline was manifested, among other things, in relation to the rules of diplomatic protocol. Embassy staff came to receptions before their ambassador 
and waited for him, as the host expects guests. Count Brockdorf-Rantzau was respected by his subordinates, was "a bright personality, a man of solid character and the embodiment of etiquette. An experienced diplomat, faithful to the traditions of the family and the Bismarck school, an aristocrat and a good politician" (AVP RF. F. 057. Op. 8. P. 105. D. 1.). His successor was Herr von Diargsen, who arrived in Moscow with his wife, who eventually became one of the most active participants in the secular diplomatic life of the capital. In the winter season of 1933, after tea at Florensky's, she went with him to a concert of working youth (singing, dancing, acrobatics). Madame Diargsen also demonstrated her performing abilities - she sat down at the piano and played "Stenka Razin". Madame behaved very casually and apparently was pleased with the evening, having personally seen how the Soviet working youth had fun (AVP RF. F. 057. Op. 13. P. 111. D. 1).

Among the Eastern states, the largest was the Embassy of Japan headed by T. Tanaka. Ambassador T. Tanaka was very fond of flowers, and during lunch the table was literally drowned in flowers despite their high cost in Moscow. The Japanese quickly adapted to the Moscow lifestyle. "Modest, undemanding, they took into account the psychological moment of the subtleties of communication and cordiality best of all, and such an understanding plays an even greater role in world politics than in purely commercial relations" (Ozols, 2015). A special position was occupied by the Embassy of Afghanistan - a buffer state between the USSR and the British Empire. Moscow spoke of Padishah Amanullah Khan as a great reformer, comparing him with Peter I, so it is not surprising that the attitude towards Afghanistan and, consequently, the embassy was more than cautious. The envoy, Mohammed Nahim Khan, received an English upbringing, but at the same time strictly adhered to religious rules. When, during one of the dinners, a representative of the People's Commissariat for Foreign Affairs spoke contemptuously about the religion of his country, he was indignant, but restrained himself. After lunch, he approached this man and said: "Don't say that another time, or I might kill you" (Ozols, 2015). In an official setting, the diplomat did not violate the rules of European etiquette, but then with his behaviour, he proved loyalty to the Eastern traditions, with which Padishah dealt very impudently, which was largely the reason for his overthrow. Later, Nahim Khan became the ruler of Afghanistan.

The political situation allowed the embassies of Turkey and Persia to be considered calmer than the embassies of the Far Eastern states. Shah Pahlavi radically reformed Persia, and Kemal Pasha - Turkey. The policy of the USSR was "rushing" between the West and the Far East, so support was needed in the Middle East. "Both the Persian and Turkish embassies liked to arrange evenings with performances by the best Russian artists. Barsova, Sobinov, Yudin sang there, the beautiful ballerina Abramova danced, and many others participated. Oriental aromatic coffee with proper serving contributed to the general fun, at these receptions we felt the peace of mind so characteristic of the Middle East", recalled (Ozols, 2015). The arrival in Moscow of the Italian Ambassador Count Manzoni and his wife gave the diplomatic corps an even greater "external gloss". The embassy preferred to listen to "serious music", Russian songs by Grechaninov (with his participation) and other composers. Count Manzoni was replaced by V. Cerutti, who also arrived with his wife. "A tall Italian and his wife - 
slender, proud, always resourceful, intelligent, reasonable, contemptuous of the Bolshevik order. V. Cerutti was very observant and understood perfectly well where Russia was heading. He proudly wore a fascist badge and was a fascist" (Ozols, 2015).

In the late 1920s, the Italian Embassy again began to play a "leading role in the life of the diplomatic corps and serve as a unifying centre" (AVP RF. F. 057. Op. 8. P. 105. D. 1.). The best reception of the whole season, according to D.T. Florinsky, was a dinner at the Italian ambassador's "organised with great taste". The reception was "embellished" by the singing of the gypsies. Countess Manzoni's dance 'Saturday parties' were replaced by Madame Cerutti's 'Tuesdays' to which only bridge players were invited. At one of these receptions, 35 people played on seven tables. D.T. Florinsky not only did not ignore such receptions, but also "took part in the game, carefully observing the behaviour of the members of the corps" (AVP RF. F. 057. Op. 13. P. 111. D. 1.). Thus, the Italian Embassy, represented by the Ambassador's wife, approved the very form of the reception, its content. England was represented in Moscow by chargé d'affaires Sir R. Hudson, commercial secretary W. Peters, secretary W. Burbury and consular officers. At first, R. Hudson was very eager to host parties inviting artists and people of aristocratic circles. But after these receptions, the authorities arrested these persons, so R. Hudson stopped hosting parties. Almost all of R. Hudson's employees spoke Russian, moved in Moscow "public circles", were well informed about the situation in the USSR, with which they wanted to establish strong relations. Poland was also moving towards the USSR. The first envoy who managed to achieve success in this was the well-known St. Petersburg lawyer S. Patek, who worked together with the embassy staff "not for fear, but for conscience". Almost all diplomats in Moscow were fond of collecting, S. Patek also collected Polish antiquities and wanted to create a museum in Warsaw named after himself.

The embassies of the Baltic states were in a special position in Moscow, as states that the USSR wanted to seize into its sphere of influence. To this end, the authorities did not disdain anything, discrediting both the states themselves and their representative offices. Such a policy of the USSR had the most negative effect on the activities of embassies, "made them nervous, forced them to $<\ldots>$ feel self-defensive. And we fought. The more they wanted to separate us, discredit us, demoralise us, the closer, stronger and friendlier we united in the embassy life", recalled (Ozols, 2015). Receptions were held quite often at the Embassy of Latvia and they were willingly attended. "How many guests, who visited our embassy, have already been shot. It is impossible to forget how wonderfully dressed ladies danced with secretaries, young attachés and respectable ambassadors, how Marshal Budyonny admired his young wife, fascinated by the overall picture of the evening, surrounded by fans, the sound of music, ballroom noise. Well-known journalists Knickerbocker, Scheffer, Durand and others met and interacted with the diplomatic corps, discussed political events, caught witty expressions, apt words and phrases on the fly. Personally, I (K. Ozols - author) liked dinners more, especially when Chicherin, a kind of interesting interlocutor, visited them" (Ozols, 2015). 
The Embassy of Finland occupied an exceptional position, it was located in the smallest mansion, in the pastor's house at the English church. The embassy, "like a beautiful pearl", attracted everyone. Minister Hazkel collected porcelain and paintings by Swedish and Finnish artists. The ambassador's wife was an exemplary hostess, the servants never took tips. Finland has become "a country of culture, order, personal dignity of people and universal well-being" (Ozols, 2015). The Lithuanian Embassy occupied a special position in Moscow largely due to the personality of the envoy J. Baltrušaitis. Coming from a family of farmers, he shepherded in the summer, and in the winter, he studied at the gymnasium, after which he entered the Moscow University, the Faculty of Physics and Mathematics, at the same time studying philology. Baltrušaitis was associated with the founder of the Symbolist school, V. Brusov, not only for his literary interests, but also as a personal friend. Together with S.A. Polyakov, he founded the publishing house of the latest literature "Scorpion". Symbolist J. Baltrušaitis was published in the almanack "Northern Flowers" and in the magazines "Libra" and "Golden Fleece". He wrote in Lithuanian, but his fame came from Russian-language works collected in the books "Earthly Steps" (1911) and "Mountain Path" (1912), as well as translations from Byron, Ibsen, D'Annunzio, Hamsun, Wilde, Strindberg. One of the poems by J. Baltrušaitis "The Bell" ends with a stanza:

\begin{abstract}
Just like the tocsin when fire is approaching
Sang the bell to a world without heed...

Loudly and sadly, one stroke on another,

Vainly it pealed about God.
\end{abstract}

"The poet Baltrušaitiswas able to overhear on both the "sorrowfulness" of strokes and the "vain" of dreams about God, rejected and forgotten in the USSR". Ozols (2015), believed that a modern diplomat should spend two years in Moscow to consider himself qualified. A similar opinion was held by the Norwegian diplomat Urbi, who collected ancient icons. Part of the collection was left unattended in a holiday home in Norway throughout the winter", - there are no thieves in the Norwegian countryside", argued Dr Urby. When tea or coffee was served in the salon by candlelight, it sometimes seemed to me that the whole room was permeated with the mysterious breath and light of the Divine. Calm wise faces of saints looked from the walls, and the ancient world was resurrected before our eyes and in our soul", recalled Ozols (2015). The absence of common borders with the USSR also protected Denmark from serious conflicts with the Soviet Union. Envoy P. Shaw worked in pre-war Russia, spoke Russian well and understood Soviet politics. The attache for agriculture, C. Koefoed, was acquainted with the Dowager Empress Maria Feodorovna, the mother of Nicholas II. The Shaw spouses arranged dinners, fun evenings and even masquerades, which were especially beloved by young people. P. Shaw loved horseback riding and together with Ozols (2015), rode in the Moscow Arena. During one of the detours of Moscow, D.T. Florinsky joined them. "As the chief of protocol, Florinsky was a godsend for the Bolsheviks. <...> Florinsky was the first chief of the protocol who decided to carry out European orders in the People's Commissariat" (Ozols, 2015).

D.T. Florinsky was obliged to meet "notable foreigners", provide tickets to the theater, issue permits to attend meetings of the Bolsheviks. K. Ozols (2015) met 
D.T. Florinsky's lodge, at one of the ballet performances, the wife of the American journalist writer J. Reed, Mrs. Bryant, who was then living in Moscow. At that time, it seemed to the diplomat that she was delighted with the Soviet order, but six months later, in Riga, Mrs. Bryant told with "great bitterness about her deceased husband J. Reed, as a faulty idealist who blindly believed in communism, his credulity having ruined him. <..> To be disappointed in life means to lose it. She was disappointed. Indirectly, the Bolsheviks were also to blame for this". The harassment organised by the State Political Directorate (GPU) against Ozols (2015), forced him to leave Moscow. Even at the beginning of his work in the capital, he sent roses from his Latvian estate as a gift to the ladies and Chicherin. He wanted as many roses as possible on his last evening in Moscow. "I wanted roses, as the supreme beauty of nature, to embody the spiritual beauty that my guests and friends showed me. So that the purity of these flowers resembles our common work and the goals to which we have always striven, purity and beauty, about which Dostoevsky said: "Beauty will save the world". "In the general atmosphere of betrayal, forgery, attacks from around the corner, which were organised by the GPU (State Political Administration) headed by the greatest bandit Yagoda, <...> I especially wanted to emphasise this. Indeed, when all the ladies with roses in their hands danced in the great hall of the embassy, a beautiful picture of common unity and inspiration presented itself to the eye. There were tears, kisses, and open protest" (Ozols, 2015).

On May 2, 1929, the entire diplomatic corps, headed by ambassadors and envoys, arrived at the Baltic Railway Station in Moscow to see off. Ozols (2015). "My wife has never received so many roses as on this day $<\ldots>$ Our salon car was drowned in them; a particularly large bouquet was presented by the Turkish ambassador. "How beautiful, how fresh the roses were!" "I remembered Turgenev's words". With this farewell, the diplomatic corps emphasised its unanimity with the diplomat. In some cases, some embassies invited only representatives of the creative Soviet intelligentsia to dinner (as guests). In March 1933, artists were invited to lunch with the Ambassador of Latvia, whose tours either took place or were scheduled in Riga. Nejdanova, Irma Jaunsen, Tikhomirov and others gathered. Sitting at the table, they waited for some time for Barsova, Vasilyeva and Lerner, who never arrived (Maksakov and Kozlovsky refused to participate in the reception). During the lunch, Ambassador Bilmanis of Latvia made a speech in which he stated that "cultural relations are a golden bridge connecting peoples and facilitating mutual knowledge for them". D.T.Florinsky drew attention to the fact that the fireplace in the dining room was decorated with Latvian and Soviet flags. The nonverbal assurance of a friendly disposition was also confirmed verbally. The Ambassador expressed a desire to get to Molotov's reception at least for a few minutes and informally - the main thing is to report on the reception to his government (AVP RF. F. 057. Op. 3. P. 101. D. 1.).

On 29 January 1938, the head of the Protocol Department, V. N. Barkov, received instructions approved by the People's Commissar of Defence, Marshal of the Soviet Union, Voroshilov, for the celebration of the 20th anniversary of the Workers' and Peasants' Red Army (WPRA). Soviet military attachés in France, England, Czechoslovakia, the USA should arrange large evening receptions, and in other countries with military attachés (Sweden, Estonia, Latvia, Poland, Bulgaria, Turkey, Afghanistan, China) "afternoon tea”. In Germany, Italy, Japan, 
organise a celebration inside the Soviet colony without inviting guests from other countries. "Tea" in Iran and Finland was supposed to be held by the plenipotentiaries (probably this was due to the fact that only the secretaries of the military attachés were there). It was decided to send a certain amount of vodka, wines, caviar only to the USA, England, France and Czechoslovakia to organise the reception (AVP RF. F. 057. Op. 18. P. 113. D. 1.). Voroshilov's instruction once again confirms the connection of the protocol with the priorities in the state's foreign policy, the problems of which were discussed by diplomats, including at official receptions. On May 10, 1939, at a reception at the Romanian envoy, on the occasion of an official holiday, at about 1 a.m., the English ambassador informed the head of the Protocol Department, V.N. Barkov, that he had received a telegram from Halifax, the contents of which he asked to convey to Molotov (the main meaning of the message was the acceleration of negotiations between the USSR and Great Britain) (AVP RF. F. 057. Op. 19. P. 113. D. 1.).

At the end of the 1930s, the life of the Diplomatic Corps in Moscow was still very busy. In the spring and summer of 1939 , receptions were given almost every day in the same way as in the 1920s. Despite the active secular diplomatic life in Moscow. Malaparte (2019), calls the Soviet capital a provincial city in which Paris and London theaters, restaurants, cinemas were enthusiastically discussed, and the work of E. Schiaparelli (1890-1973), a legendary fashion designer, founded her own fashion house in Paris, was preferred to the work of European writers; J. Paquin (1869-1936) - one of the first women couturiers; L. Lolonga (1889-1958) Parisian couturier; M. Ruffa (1896-1971) - French fashion designer; E. Milino (1891-1974) - British fashion designer. "Among the communist nobility, whose style is not innate, but affected, as among the parvenus in bourgeois society, restraint and simplicity of manners are replaced by suspicion. The main difference between the communist nobility is not bad taste, not rudeness, not bad manners, not admiring wealth, chic, power, but suspicion and even, I would say, ideological intolerance". Malaparte (2019), admits that the entire diplomatic corps "with one voice" praised Stalin's lifestyle, while emphasising that he did not belong to the "communist nobility". He compares him to N. Bonaparte after 18 Brumaire (November 9), 1799, when the Directory was dispersed in France and a government headed by N. Bonaparte came to power. Stalin was the master, the dictator, the "communist nobility" was against him.

"Snobbery was the secret spring of all the secular events of this most important and already decayed society. Yesterday they were still living in poverty, under suspicion, in the precarious position of underground workers and emigrants, and then suddenly they were sleeping in tsarist beds, sitting in gilded armchairs of the highest officials of tsarist Russia, playing the same role that yesterday the imperial nobility played. Each of the representatives of the New nobility tried to imitate Western manners: ladies - Parisian, gentlemen - London, a minority Berlin or New York" (Malaparte, 2019). In the 1920s, the famous "coach from Spiridonovka" was one of the strongest tennis players in Moscow and the country, B.A. Ulyanov (1891-1951) - an athlete, journalist, lawyer, mathematician. He initiated the creation of the Moscow Lawn Tennis League (1913), secretary of the Lawn Tennis Commission of the Moscow Ski Club (1912-1913), chairman of the lawn tennis department of the Moscow Union Sports Club (1914-1916). In 1923 and 1925, B.A. Ulyanov was a finalist of the Moscow Championships in singles. 
As part of the Moscow team, he was the winner of the All-Union Spartakiad of 1928 and the RSFSR Team Championship (1927-1928). B.A. Ulyanov was one of the most famous characters of secular Moscow and, in all probability, was the personal trainer of the Deputy People's Commissar of Foreign Affairs L.M. Karakhan, during whose game he closely followed "his every gesture, every movement, dispassionately, slightly squinting, assessing his every blow <..." Malaparte (2019).

"Karakhan played tennis beautifully and appeared every day on the courts of the mansion on Spiridonovka or the English Embassy, dressed in an immaculate set of white flannel, in white tennis shoes with red rubber soles, which recently came into fashion and which were called Japanese shoes. He played easily, freely, uninhibited, soupl (fr. smoothly), with a smile" (Malaparte, 2019). L.M. Karakhan played only with balls sent from London. Explaining this by the fact that Soviet balls are hard. To the wife of the British ambassador, Lady Ovey, he said with perfect Oxford pronunciation: "Marx did not foresee that English tennis balls would be better than Soviet ones. Marx lived in Soho and the East End. They don't play tennis in London's East End, isn't it?" (Malaparte, 2019). L.M. Karakhan's bravado caused irritation and surprise at the same time. The representative of the "Soviet nobility" felt a deep admiration for Europe (pour n'importe quelle Europe (no matter which Europe (French), as the French ambassador J. Herbette said). On May 3, 1937, L.M. Karakhan was summoned to Moscow from Ankara under the pretext of being reassigned to the post of ambassador to the United States. When leaving the train, he was arrested and shot on September 20, 1937. On June 2, 1937, despite the arrest of her husband, the outstanding Soviet ballerina M. Semenova was awarded the Order of the Red Banner of Labour. In totalitarian states, art and sports are one of the main factors of political propaganda, the main purpose of which is the affirmation and dissemination of party values.

\section{Corporate life of the diplomatic corps in London (the 1930s)}

One of the problems of Soviet diplomacy in the 1920s-30s was that Soviet citizens accepted for service in the People's Commissariat of Foreign Affairs in the 1920s1930 s, for the most part, were not ready to perform diplomatic duties. They had to master the norms of the European protocol both at home and in the countries of their accreditation, to adapt to the local traditions of diplomatic life. In the early 1920s, diplomats gathered in Moscow at the British mission. It was no coincidence. Great Britain was an actor in world politics, a state whose possessions spread "across all seas and oceans". In the 1930s, the USSR ambassador in London was Maisky (1971). During this period, there were 51 representative offices in the capital of the empire, the number of members of the diplomatic corps in which was over 300 people (together with families of about 1,000 people). One of the main tasks of the ambassador is to establish relations with the diplomatic corps. According to Maisky (1971), this "noisy and large diplomatic colony" was distinguished by "diversity and multiplicity". At that time, the USSR maintained diplomatic relations with 20 of the 51 states that had their representative offices in England. "These were England, France, Germany, Italy, Japan, Turkey, Persia, Denmark, Afghanistan, China, Austria, Norway, Sweden, Finland, Estonia, Latvia, Lithuania, Poland, Bulgaria and Greece”. The remaining 
three dozen, including the United States, "pretended not to notice the existence of a Soviet country on our planet".

There was no "close corporate life" of the corps in London, which Maisky (1971), observed in Tokyo and Helsinki, where he had worked before. In Tokyo, the corps in the early 1920s represented a very special sphere, sharply limited from the surrounding Japanese environment. Contacts between the diplomatic corps and local residents were limited and fragile. The difference of languages, cultures, the general way of life, and partly - purely "police slingshots" interfered. As in any "closed world", in the Tokyo diplomatic colony one could find friendship, enmity, quarrels, gossip, rivalry of ladies, competition of husbands, love escapades, search for suitors, weddings and divorces. Dr. Solf, formerly the naval minister of Kaiser Wilhelm, and in the 1920s the German ambassador and doyen of the diplomatic corps in Tokyo, liked to ask: "Well, what is new in Notre village diplomatique (Fr. in our diplomatic village)?". In London, the situation was different. When Maisky (1971) visited, shortly after the presentation of credentials, the doyen of the Corps de Fleuriot, he told him: "The diplomatic corps here is very fragmented. There is no corporate life. Diplomats rarely meet with each other, and even then, mostly with the British: at receptions, dinners, and so on, arranged either by the British government or representatives of the British nobility, British business circles. I have been a doyen for several years now, but there are heads of missions who have never been to me and whom I have never been to. It seems that I don't even know everyone by sight".

The reason for the lack of corporate life of the diplomatic corps in London was not in the language, almost all diplomats in London spoke English, there were no police "slingshots" - one could meet and talk to whomever they wanted. There were enough people in London who could invite up to a thousand people to an evening at once. "For foreign diplomats in England, the difficulty was not that there were too few "secular invitations", and that there were too many of them $<\ldots>$ and, finally, the diplomatic corps in London (excluding Soviet diplomats) looked down on the side of their stay, this applied decisively to all foreign representatives of the capitalist world, not excluding Americans" (Maisky, 1971). The diplomatic custom codified by the Congress of Vienna in 1815 provides that after the presentation of credentials, the ambassador pays courtesy visits to other ambassadors already accredited in this country, after which the ambassadors pay him a return visit. Envoys, usually representing countries of the second and third rank, are the first to pay a visit to the newly appointed ambassador, after which the ambassador pays them a return visit. (After the Second World War, almost all countries elevated their diplomatic representatives to the rank of ambassadors). Maisky (1971), introduces a democratic innovation into the traditional protocol, which, according to him, stems from the "spirit of our era and the character of the state" that he represented. The Soviet diplomat visited first all the ambassadors, and then all the envoys of those countries that maintained diplomatic relations with the USSR.

As a result, he quickly became acquainted and established the contacts he needed. The behaviour of the Soviet ambassador was unusual and became the reason for the discussion. The explanation for Maisky (1971), was formulated by Vogt, the Norwegian envoy to London, in an interview with a journalist: "The new 
Bolshevik ambassador is not proud and makes no distinction between representatives of great and small powers. M.M. Litvinov approved of the ambassador's behaviour, which strengthened "the prestige of the USSR as a carrier of advanced ideas of humanity in all matters, large and small". The exchange of protocol visits between heads of missions and their wives is a diplomatic tradition. Maysky's wife paid visits to the wives of ambassadors and envoys of all those countries with whom the USSR maintained diplomatic relations. For the political atmosphere of the 1930s, everything went well. Except for a few cases. After one of them, namely with the wife of the Minister of Foreign Affairs Lady Simon, the Minister's wife did not make a return visit, but limited herself to sending her business card, which is acceptable from the point of view of protocol, but meant that "the temperature of our relations is close to zero". The meeting with the wife of the Permanent Deputy Minister of Foreign Affairs, Lady Vansittart, went differently. The ladies had a long conversation in the Vansittart library about art, literature, poetry. Then Lady Vansitart made a return visit to Maysky's wife, at the end of which the Soviet diplomat went to the salon. The good relations of the ladies had a beneficial effect on the relations of the Soviet diplomat with Vansittart.

But the "visiting campaign" of the wife of Maysky was not always successful. The general atmosphere of relations with the USSR is illustrated by the visit to the wife of the doyen of the corps, Madame de Fleuriot, who received the guest surrounded by the secretaries of the French embassy, one of whom was her translator. During the return visit, Madame handed Maysky's wife a pack of her business cards, with which she had to pay visits to the wives of other diplomats. Etiquette requires that the doyen's wife personally introduce the newly arrived ambassador's wife to the wives of the ambassadors already in place. Madame's refusal was allowed by etiquette, but such a form meant "coldness of relations" between the representative and the represented. Another area of activity of the ambassador's wife is maintaining contacts with the wives of ministers, diplomats, politicians, public figures. Such connections, especially in the USA, England, France, allow the ambassador to be aware of events taking place in government circles. Maisky (1971), proposes to organise special training for the wives of future ambassadors and envoys, including acquaintance with literature, art and other areas of culture, which would contribute to successful diplomatic work. During his protocol visits, the Soviet diplomat also visits the Austrian envoy Baron Georza von Frankenstein, who in 1920 was appointed to London as the envoy of the post-war Austrian Republic. A luxurious house in a fashionable part of London testified to the former imperial power. Before the war, the embassy hosted brilliant balls and fun carnivals, but now there was not enough money even for repairs.

Despite this, Maisky (1971), notes that from a diplomatic point of view, Frankenstein was a very good diplomat. He used every opportunity in the interests of Austria. In this case, I. Maisky was referring to receptions held at the embassy, at which English and Austrian singers, actors, composers, directors, artists met. Festivals, exhibitions, concerts organised by the envoy contributed to the fact that the embassy turned into a centre of cultural life, it was talked about, it was singled out among other missions and equated with the embassies of great powers. "Thus, with the help of the muses, Frankenstein to a certain extent 
compensated for the lack of political influence of post-war Austria. If it were not for that, his embassy would simply have turned into a small, run-down office for Austrian affairs". After the occupation of Austria by German troops in March 1938, Frankenstein resigned and refused to serve Hitler. On June 25, 1938, the English king granted him the English nobility. Sir Frankenstein went into business, which was provided to him by English friends. For people far from the problems of the diplomatic service, receptions are a place of rest. For professionals- it is a place of communication, as well as receiving and transmitting information.

In the autumn of 1970 , at a cocktail party and a closed pre-auction viewing of paintings by contemporary Soviet artists, Karyagin (1994), who was in the diplomatic service in London at the time, in conversation with J. Morgan (who was in charge of "Soviet affairs" at the Foreign Office at that time) learned that an exhibition of ancient Chinese drawings would be organised in London, which was agreed through the channels of the British Council (a semi-governmental organisation operating under the auspices of the Ministry of Foreign Affairs in the field of cultural, scientific and other humanitarian exchanges); in exchange, Beijing would receive the London Symphony Orchestra. "Is that ping-pong in English manner?" asked Karyagin (1994), meaning a Chinese-American table tennis match that marked the beginning of active relations between the United States and the People's Republic of China (PRC). "Just that so far, but tempting, isn't it?" - replied J. Morgan. "Ping pong diplomacy" has become a household name. In pre-war history, there is a case when "the famous French journalist G. Tabouis deduced her sensation about the Soviet-German rapprochement from the broadcast of Tchaikovsky's First Concert by the Berlin radio station". The "symphonic ping-pong" helped accelerate the process of rapprochement between the two countries, and soon diplomatic exchanges between London and Beijing rose to the level of embassies. In ping-pong diplomacy, the dominant factor is cultural exchange (Karyagin, 1994).

\section{Conclusions}

The diplomatic corps is a public institution in the life of which art is one of the most important communicative factors. As a result of the study, the following main lines of communication were identified: diplomatic corps - government; government - diplomatic corps; diplomatic corps - public organisations; diplomatic corps - NKID; NKID (MFA) - diplomatic corps. The subjects of communication are diplomatic workers, embassy staff and their family members, government and public figures, employees of the NKID (MFA), representatives of the creative intelligentsia. The main factors of communication are concert programmes, opera and ballet art, drama theatre, sports, diplomatic gifts and the language of costume. After the October revolution of 1917, representatives of the diplomatic corps became the original heirs of the pre-revolutionary lifestyle of the Russian elite.

At the official level, Soviet leaders "fought" with various manifestations of the bourgeois way of life, and at the same time actively participated in the Soviet life of the diplomatic corps. The peculiarity of the diplomatic corps' stay in Moscow is that the diplomats were in a new, unusual for them socio-cultural environment in 
which there was a negative attitude towards modern European culture, representatives of which were also members of the diplomatic corps. Diplomats from other countries were a kind of "bearers" of European cultural values alien to Soviet ideology, diplomatic immunity extended to culture as well. In turn, the diplomats reported to their countries about the figures of the "unofficial" Soviet culture, thereby informing about the art directions banned in the USSR. But in this case, the cultural exchange was political in nature. The main goal is not to educate society, but to force the political elite to enter into the negotiation process, to make it an ally in the system of international relations.

\section{References}

Baack, D. W., \& Singh, N. (2007). Culture and web communications. Journal of business research, 60(3), https://doi.org/10.1016/j.jbusres.2006.11.002

de Melu, R. F. (1953). Treatise on diplomatic law. Madrid: Planeta.

Diachenko, S., Buha, V., Shchetinina, T., Olentiev, R., \& Uhodnikova, O. (2021). Formation of priorities for the public education management system development. Linguistics and Culture Review, 5(S4), 358-370.

Dodd, M. D., \& Collins, S. J. (2017). Public relations message strategies and public diplomacy 2.0: An empirical analysis using Central-Eastern European and Western Embassy Twitter accounts. Public relations review, 43(2), 417425. https:/ / doi.org/10.1016/j.pubrev.2017.02.004

Gene, R. (1931). Diplomatic treaties and diplomatic law. Paris: Gallimard.

Ginaya, G., Rejeki, I. N. M., \& Astuti, N. N. S. (2018). The effects of blended learning to students' speaking ability: A study of utilizing technology to strengthen the conventional instruction. International Journal of Linguistics, Literature and Culture, 4(3), 1-14

Hogan, K., Baer, A., \& Purtilo, J. (2021). Diplomat: A conversational agent framework for goal-oriented group discussion. Lecture Notes in Business Information Processing, 420, 143-154.

Karyagin, V. V. (1994). Diplomatic life behind the scenes and on stage. Moscow: Mezhdunarodnyye otnosheniya.

Keller, H., Otto, H., Lamm, B., Yovsi, R. D., \& Kärtner, J. (2008). The timing of verbal/vocal communications between mothers and their infants: A longitudinal cross-cultural comparison. Infant Behavior and Development, 31(2), 217-226. https://doi.org/10.1016/j.infbeh.2007.10.001

Keys, B., \& Yorke, C. (2019). Personal and Political Emotions in the Mind of the Diplomat. Political Psychology, 40(6), 1235-1249.

Korolova, V. V., Dolhoruchenko, K. O., Oliinyk, O. B., Glukh, M. V., \& Hrytsiak, I. A. (2021). International legal aspects of migration in the EU: policies and standards. Linguistics and Culture Review, 5(S3), 539-553.

Kvasov, O. K. (2011). Protocol and etiquette: Diplomatic, business, civil. Moscow: Vostok-Zapad.

Lima R. C., \& de Oliveira, A. J. S. N. (2018). Continuity and change in the ministry of foreign affairs: A profile of the diplomatic corps and career patterns. Revista de Administracao Publica, 52(5), 797-821.

Lockett, A., Siegel, D., Wright, M., \& Ensley, M. D. (2005). The creation of spin-off firms at public research institutions: Managerial and policy 
implications. Research

policy, 34(7),

981-993.

https://doi.org/10.1016/j.respol.2005.05.010

Lyadov, P. F. (2018). History of the Russian protocol. Moscow: Mezhdunarodnyye otnosheniya.

Maisky, I. (1971). Memoirs of a Soviet diplomat, 1925-1945. Moscow: Nauka.

Malaparte, K. (2019). Ball in the Kremlin. Moscow: Redaktsiya Yeleny Shubinoy.

Molochkov, F. F. (1977). Diplomatic protocol and diplomatic practice. Moscow: Mezhdunarodnyye otnosheniya.

Moro, S., Pires, G., Rita, P., \& Cortez, P. (2020). A cross-cultural case study of consumers' communications about a new technological product. Journal of Business Research, 121,

https://doi.org/10.1016/j.jbusres.2018.08.009

Ozols, K. (2015). Memoirs of the ambassador. Moscow: Tsentrpoligraf.

Pradee-Fodere, P. (1881). Course of diplomatic law. Paris: Gallimard.

Robinson, N., \& Martin, K. (2017). Distributed denial of government: The Estonian data embassy initiative. Network Security, 2017(9), 13-16. https:/ / doi.org/10.1016/S1353-4858(17)30114-9

Scoville, R. M. (2019). Unqualified ambassadors. Duke Law Journal, 69(1), 71196.

Sreejith, S. G. (2019). The fallen envoy: the rise and fall of astronaut in International Space Law. Space Policy, 47, 130-139. https://doi.org/10.1016/j.spacepol.2018.10.004

Sundqvist, S., Frank, L., \& Puumalainen, K. (2005). The effects of country characteristics, cultural similarity and adoption timing on the diffusion of wireless communications. Journal of business research, 58(1), 107-110. https:/ / doi.org/10.1016/S0148-2963(02)00480-0

Suwija, N., Suarta, M., Suparsa, N., Alit Geria, A.A.G., Suryasa, W. (2019). Balinese speech system towards speaker social behavior. Humanities \& Social Sciences Reviews, 3(5), 32-40. https:/ / doi.org/10.18510/hssr.2019.754

Tödtling, F., \& Trippl, M. (2005). One size fits all?: Towards a differentiated regional innovation policy approach. Research policy, 34(8), 1203-1219. https://doi.org/10.1016/j.respol.2005.01.018

Watkins, J. (2019). Afterword: Diplomats as readers and writers. Huntington Library Quarterly, 82(4), 641-649.

Wesnawa, I. G. A., \& Sudirta, I. G. (2017). Management of boundary areas based on Nyamabraya values. International Journal of Linguistics, Literature and Culture, 3(5), 63-71.

Wood, D., \& Serre, J. (2016). Diplomatic ceremony and protocol. Moscow: Mezhdunarodnyye otnosheniya.

Yun, S. H. (2007). Exploring the embassy sampling strategy for large-scale crossnational study in replicating the normative theory of global public relations. Public Relations Review, 33(2), 224-226. https://doi.org/10.1016/j.pubrev.2007.02.010 